\title{
Further Studies on the Effect of Exogenous Progesterone and Related Compounds on the Preovulatory Progesterone Secretion in the Rat
}

\author{
KiYohisa UCHIDA, Masumi KADOWAKI and TAMOTSU MIYAKE \\ Shionogi Research Laboratory, Shionogi \& Co., Ltd. \\ Fukushima-ku, Osaka
}

\begin{abstract}
Synopsis
Further studies were made in 4-day cyclic rats on the action of exogenous progesterone in advancing the release of LH from the pituitary, evidenced by the earlier increase in ovarian progesterone secretion than the spontaneous preovulatory increase in secretion of this steroid. It was found that 1) exogenous progesterone injected subcutaneously during the period from 03.00 to $13.00 \mathrm{hr}$ of proestrus increased the rate of ovarian progesterone secretion at $16.00 \mathrm{hr}$ on that day, one hr earlier than the time of the spontaneous increase corresponding to the onset of LH release, maximal increase being induced by progesterone given at $11.00 \mathrm{hr}$, injections at 01.00 or $15.00 \mathrm{hr}$ failed to increase the secretion;2) a linear dose-response relationship between the secretory rate of progesterone and the log-dose of progesterone injected at $11.00 \mathrm{hr}$ was obtained in the dosage range of 0.05 to $5 \mathrm{mg}$ per rat; 3 ) advanced increase in progesterone secretion caused by an adequate amount of progesterone was seen around $14.00 \mathrm{hr}$ at the earliest, regardless of the time of progesterone injection, i.e. the advancement of $\mathrm{LH}$ release by exogenous progesterone never exceeded $3 \mathrm{hr}$; 4) desoxycorticosterone (DOC), norethisterone and medroxyprogesterone acetate (MAP) exerted a similar effect but corticosterone and medroxyprogesterone did not; 5) the progesterone secretory rate at 16.00 or $19.00 \mathrm{hr}$ in rats sufficiently primed with progesterone was almost double the maximal value obtained at the peak of LH release in intact rats, and such a "supersecretion" of progesterone was not obtained by an LH preparation, even when given in excess; 6) $20 \alpha$-hydroxypregn-4-en-3-one (20 $\alpha$ $\mathrm{OH}-\mathrm{P})$ secretion was not always parallel with progesterone secretion under the various conditions described above; and 7) treatment with $5 \mathrm{mg}$ of progesterone, medroxyprogesterone, corticosterone or DOC increased the ovarian secretory rate of $20 \alpha-\mathrm{OH}-\mathrm{P}$ but either smaller doses of progesterone, or the treatment before $05.00 \mathrm{hr}$ on the day of proestrus, appeared to depress the secretion of this steroid.

From these results, it is suggested that exogenous progesterone not only acts on the neural process regulating the ovulating hormone release from the pituitary but also affects the ovary to increase its responsiveness to pituitary gonadotropins, and thus advances the release of ovulating hormone and causes the supersecretion of progesterone at the preovulatory state. It is further suggested that exogenous progesterone and synthetic progestins directly or indirectly affect the ovarian production of $20 \alpha-\mathrm{OH}-\mathrm{P}$.
\end{abstract}

Our previous work (Uchida et al., 1969c) demonstrated that a single subcutaneous injection of progesterone into cyclic rats early on the day when the proestrus set in caused an advancement in ovarian progesterone secretion mediated through the release of luteinizing hormone $(\mathrm{LH})$ from the pituitary, while

Received for publication February 19, 1970.

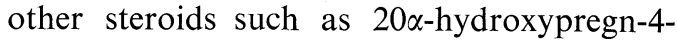
en-3-one (20 $\alpha-\mathrm{OH}-\mathrm{P})$, estradiol, estriol, testosterone, and 5-androstenediol, provided no promoting effect on preovulatory progesterone secretion. From these experiments, it was noticed that the ovarian progesterone secretory rate was greater in rats injected with progesterone in the forenoon than in those given the steroid in the afternoon. This fact 
suggests that there might be an optimal time for progesterone injection to evoke the release of LH from the pituitary and a subsequent increase in ovarian progesterone secretion. The present experiments are focussed mainly on a detailed study of this point.

It is also known that endogenous C-21 steroids other than progesterone, e.g. corticosterone and desoxycorticosterone (DOC), exert progesterone like activity in various bioassays based on rabbit endometrial proliferation (Engle and Noble, 1956 and 1957), restoration of the estrous cycle in persistent estrous rats (Marvin, 1947), the copulatory reflux in guinea pigs (Byrnes and Shipley, 1955; Marvin, 1958), and on the induction of ovulation in immature rats primed with pregnant mare's serum gonadotropin (McCormack and Meyer, 1965). In comparison with progesterone, these progestational C - 21 steroids and other synthetic progestins such as norethisterone (17 $\alpha$-ethynyl-17 $\beta$-hydroxyestr4-en-3-one), medroxyprogesterone (6 $\alpha$-methyl-17 $\alpha$-hydroxypregn-4-ene-3, 20-dione) and its acetate (MAP) were examined for their effects on preovulatory progesterone secretion, the prompt increase of which reflects the release of $\mathrm{LH}$, an ovulating hormone, from the pituitary.

\section{Materials and Methods}

Wistar strain female rats weighing 170 to $200 \mathrm{~g}$ were reared with an ordinary rat chow and water $a d$ libitum in an air-conditioned room $\left(25 \pm 1{ }^{\circ} \mathrm{C}, 50-60 \%\right.$ humidity) illuminated $12 \mathrm{hr}$ a day (08.00-20.00 hr). Vaginal smears were examined every morning and rats exhibiting a regular 4-day estrous cycle were used after they had completed at least three normal cycles.

The rats were injected subcutaneously with progesterone and other steroids in $0.2 \mathrm{~m} l$ sesame oil at varying times on the day the proestrus. One to several hours after the injection, ovarian secretory rates of progesterone and $20 \alpha-\mathrm{OH}-\mathrm{P}$ were determined according to the method reported in the previous paper (Uchida et al., 1969a).

\section{Results}

First, one injection of $5 \mathrm{mg}$ of progesterone was given subcutaneously to each proestrous rat at varying times at intervals of $2 \mathrm{hr}$ from 01.00 to $15.00 \mathrm{hr}$, and the secretory rates of progesterone and $20 \alpha-\mathrm{OH}-\mathrm{P}$ were determined at $16.00 \mathrm{hr}$ on the same day. The data are presented in Figure 1, illustrating the relationships between the secretory rates of both progestins and the time of progesterone injection. The progesterone injection at $01.00 \mathrm{hr}$ has no effect on the ovarian progesterone secretion at $16.00 \mathrm{hr}$ but appears to cause a depression in the rate of $20 \alpha-\mathrm{OH}-\mathrm{P}$ secretion. Progesterone secretion increases in accordance with a shift of the time of progesterone injection; the highest response is obtained when progesterone is injected at $11.00 \mathrm{hr}$, a later injection at 13.00 or $15.00 \mathrm{hr}$ produces a lower or no response. The rate of markedly increased secretion of progesterone produced by injecting progesterone at 09.00 or $11.00 \mathrm{hr}$ is almost twice as much as the maximal level (around $3 \mu \mathrm{g} / \mathrm{hr} /$ ovary) of the intact rats, obtained during the proestrus from 17.30 to $23.00 \mathrm{hr}$ (Uchida et al., 1969a and 1969b). As shown in Figure 1, 20 $\alpha-\mathrm{OH}-\mathrm{P}$ secretion appears to change in parallel with progesterone secretion. However, when progesterone is given before $05.00 \mathrm{hr}$, the secretory rate of

Table 1. Effect of various doses of progesterone injected at $11.00 \mathrm{hr}$ on ovarian secretory rates of progesterone and 20 $\alpha$-hydroxypregn-4-en-3one $(20 \alpha-\mathrm{OH}-\mathrm{P})$ at $16.00 \mathrm{hr}$ on the day of proestrus in 4-day cyclic rats

\begin{tabular}{cccc}
\hline $\begin{array}{c}\text { Dose of } \\
\text { progesterone } \\
\text { injected } \\
(\mathrm{mg} / \mathrm{rat})\end{array}$ & $\begin{array}{c}\text { Number } \\
\text { of } \\
\text { rats }\end{array}$ & \multicolumn{2}{c}{$\begin{array}{c}\text { Ovarian secretion } \\
(\mu \mathrm{g} / \mathrm{hr} / \text { ovary })\end{array}$} \\
\hline 0 & 9 & $0.36 \pm 0.08^{*}$ & $7.82 \pm 1.73^{*}$ \\
0.05 & 7 & $0.29 \pm 0.07$ & $4.83 \pm 0.69$ \\
0.2 & 6 & $1.52 \pm 0.21$ & $4.94 \pm 0.48$ \\
0.5 & 7 & $1.56 \pm 0.23$ & $7.68 \pm 1.43$ \\
1 & 7 & $3.60 \pm 0.35$ & $6.38 \pm 1.08$ \\
5 & 6 & $6.20 \pm 0.82$ & $12.87 \pm 1.60$ \\
\hline
\end{tabular}

Mean \pm S.E. 


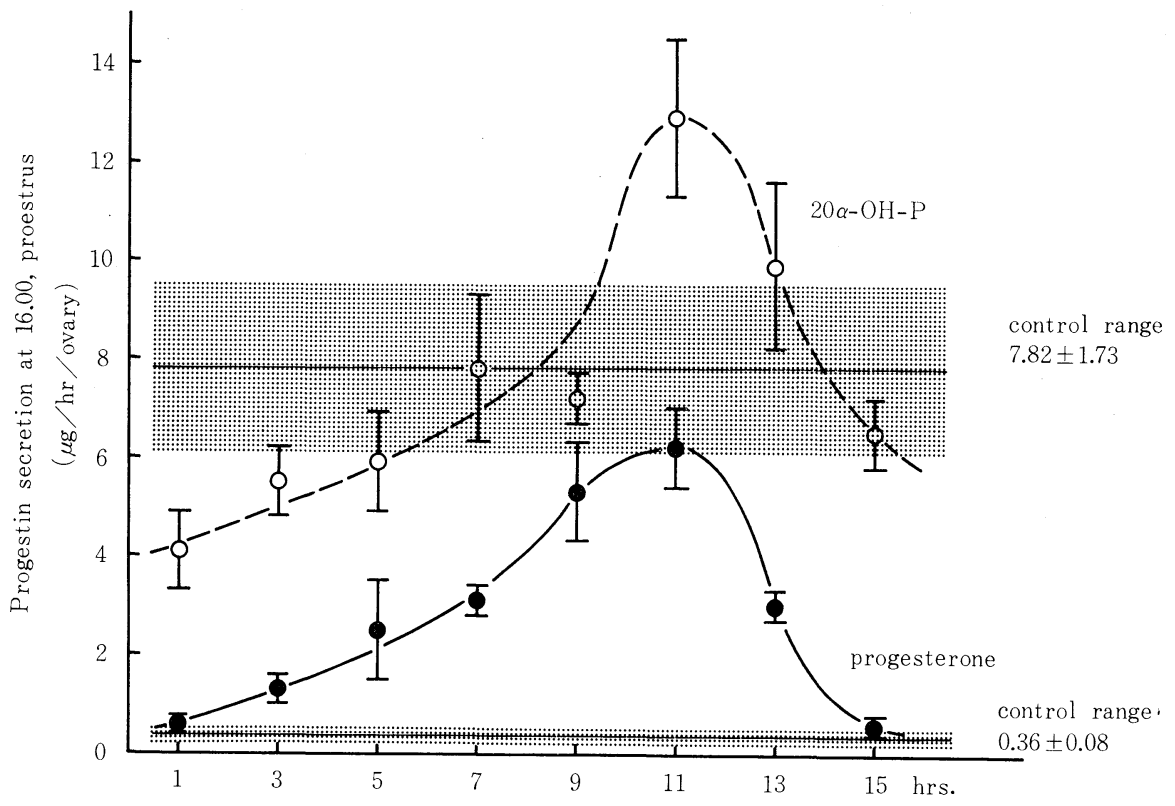

Time of progesterone injection on proestrus

Fig. 1. Relationship between the time of exogenous progesterone injection (in the abscissa) and the secretory rates $\left(\mu \mathrm{g} / \mathrm{hr} /\right.$ ovary, in the ordinate) of ovarian progesterone and $20 \alpha_{-}$ hydroxypregn-4-en-3-one ( $20 \alpha-\mathrm{OH}-\mathrm{P})$ at $16.00 \mathrm{hr}$ on the day of proestrus in 4-day cyclic rats. Points and bars indicate the mean values and standard errors in 6 to 11 rats, respectively. A dose of $5 \mathrm{mg}$ per rat of progesterone in $0.2 \mathrm{~m} l$ sesame oil was subcutaneously injected once at the varying time indicated. Control values were obtained from the rats given vehicle alone at $13.00 \mathrm{hr}$ on the same day.

Table 2. Ovarian secretory rates of progesterone and $20 \alpha$-hydroxypregn-4-en-3-one (20 $\alpha-\mathrm{OH}-\mathrm{P})$ at various times after the injection of progesterone at $09.00,13.00$, or $15.00 \mathrm{hr}$ on the day of proestrus

\begin{tabular}{|c|c|c|c|c|}
\hline \multirow{2}{*}{$\begin{array}{l}\text { Treatment } \\
\text { in } \\
\text { proestrus }\end{array}$} & \multirow{2}{*}{$\begin{array}{l}\text { Time of } \\
\text { blood } \\
\text { collection }\end{array}$} & \multirow{2}{*}{$\begin{array}{c}\text { Number } \\
\text { of } \\
\text { rats }\end{array}$} & \multicolumn{2}{|c|}{ Ovarian secretion of $(\mu \mathrm{g} / \mathrm{hr} /$ ovary $)$} \\
\hline & & & Progesterone & $20 \alpha-\mathrm{OH}-\mathrm{P}$ \\
\hline \multicolumn{5}{|c|}{ Control (Sesame oil, $0.2 \mathrm{ml} / \mathrm{rat}$ ) } \\
\hline 1300 & 1600 & 9 & $0.36 \pm 0.08 * *$ & $7.82 \pm 1.73 * *$ \\
\hline & 1900 & 10 & $3.06 \pm 0.30$ & $7.71 \pm 0.63$ \\
\hline \multicolumn{5}{|c|}{ Progesterone ( $5 \mathrm{mg} / \mathrm{rat})$} \\
\hline 0900 & 1300 & 6 & $0.31 \pm 0.05$ & $8.27 \pm 1.30$ \\
\hline 0900 & 1400 & 7 & $0.56 \pm 0.18$ & $9.01 \pm 1.20$ \\
\hline 0900 & 1500 & 7 & $2.44 \pm 0.63$ & $6.51 \pm 1.00$ \\
\hline 0900 & 1600 & 7 & $5.28 \pm 1.04$ & $7.21 \pm 0.48$ \\
\hline 1300 & 1400 & 6 & $1.21 \pm 0.24$ & $4.77 \pm 0.45$ \\
\hline 1300 & 1500 & 6 & $2.90 \pm 0.55$ & $7.62 \pm 1.55$ \\
\hline 1300 & 1600 & 7 & $3.04 \pm 0.29$ & $9.88 \pm 1.69$ \\
\hline 1300 & 1900 & 11 & $4.95 \pm 0.73$ & $6.71 \pm 0.49$ \\
\hline 1500 & 1900 & 12 & $5.76 \pm 0.79$ & $8.10 \pm 1.12$ \\
\hline
\end{tabular}

* Ovarian venous blood was collected for $15 \mathrm{~min}$ from the time indicated in the table.

** Mean \pm S. E. 
$20 \alpha-\mathrm{OH}-\mathrm{P}$ falls below the level in controls receiving the vehicle alone, though it is higher than that of the control range when progesterone is administered at 11.00 or $13.00 \mathrm{hr}$.

The above results show that $11.00 \mathrm{hr}$ is the optimal time for progesterone injection to increase the secretory rate of progesterone at $16.00 \mathrm{hr}$ on the day of proestrus. Accordingly, varying dosages of progesterone were given at $11.00 \mathrm{hr}$ and the ovarian secretory rates of progesterone and $20 \alpha-\mathrm{OH}-\mathrm{P}$ were determined at $16.00 \mathrm{hrs}$. The data are presented in Table 1, showing that the secretory rate of progesterone rises in proportion to the amount of progesterone administered. Such a clear dose-response relationship, however, is not seen for $20 \alpha-$ OH-P secretion. The secretory rate of $20 \alpha-$ OH-P appears to be decreased by small dosages of progesterone while it is increased by larger dosages.

In order to ascertain the exact time when ovarian progesterone secretion starts to increase after giving exogenous progesterone, a dosage of $5 \mathrm{mg}$ per rat of progesterone was injected subcutaneously either at 09.00 or at $13.00 \mathrm{hr}$ and ovarian progestin secretory rates were determined at 13.00, 14.00, 15.00, 16.00, and $19.00 \mathrm{hr}$. The data are given in Table 2 . In the controls receiving vehicle alone, pro- gesterone secretion is as low as $0.36 \mu \mathrm{g} / \mathrm{hr} /$ ovary at $16.00 \mathrm{hr}$ but it increases almost tenfold over the next $3 \mathrm{hr}$ to $3.06 \mu \mathrm{g} / \mathrm{hr} /$ ovary, confirming the results reported previously (Uchida et al., 1969a). In the rats treated with progesterone, the ovarian progesterone secretion was slightly higher at $14.00 \mathrm{hr}$ and apparently higher at $15.00 \mathrm{hr}$ or later, than that in controls at $16.00 \mathrm{hr}$ regardless of the time of progesterone injection. These data suggest that the $\mathrm{LH}$ release is advanced only 2 to $3 \mathrm{hr}$ by exogenous progesterone, since spontaneous LH release starts in our rats at around 17.00 $\mathrm{hr}$ and attains a peak at $19.00 \mathrm{hr}$. (Kobayashi et al., 1968), and the drastic increase in progesterone secretion at proestrous stage entirely depends on the pituitary LH discharge (Uchida et al., 1969a).

Effects of norethisterone, medroxyprogesterone, MAP, corticosterone, and DOC on the ovarian secretory rates of progestins were examined under the same conditions as those used for progesterone. The data are given in Table 3. Norethisterone, MAP and DOC increase ovarian progesterone secretion but medroxyprogesterone and corticosterone do not. Either norethisterone or MAP injected at $09.00 \mathrm{hr}$ provides a more significant response in progesterone secretion than that injected

Table 3. Effects of norethisterone, medroxyprogesterone and its acetate, corticosterone and desoxycorticosterone on ovarian secretory rates of progesterone and $20 \alpha$-hydroxypregn-4-en-3-one (20 $\alpha-\mathrm{OH}-\mathrm{P})$ at 16.00 and at $19.00 \mathrm{hr}$ on the day of proestrus

\begin{tabular}{lccccc}
\hline $\begin{array}{c}\text { Treatment } \\
(5 \mathrm{mg} / \mathrm{rat})\end{array}$ & $\begin{array}{c}\text { Time } \\
\text { of } \\
\text { injection }\end{array}$ & $\begin{array}{c}\text { Time of } \\
\text { blood } \\
\text { collection* }\end{array}$ & $\begin{array}{c}\text { Number } \\
\text { of } \\
\text { rats }\end{array}$ & $\begin{array}{c}\text { Ovarian secretion } \\
(\mu \mathrm{g} / \mathrm{hr} / \text { ovary }) \\
20 \alpha-\mathrm{OH}-\mathrm{P}\end{array}$ \\
\hline Control & 1300 & 1600 & 9 & $0.36 \pm 0.08^{* *}$ & $7.82 \pm 1.73 * *$ \\
Norethisterone & 0900 & 1600 & 6 & $3.45 \pm 0.61$ & $6.00 \pm 1.01$ \\
& 1300 & 1600 & 11 & $1.10 \pm 0.30$ & $6.42 \pm 0.94$ \\
Medroxyprogesterone & 1300 & 1900 & 7 & $4.25 \pm 0.63$ & $9.31 \pm 1.39$ \\
& 0900 & 1600 & 9 & $0.26 \pm 0.04$ & $11.29 \pm 1.53$ \\
MAP & 1300 & 1600 & 5 & $0.68 \pm 0.11$ & $11.15 \pm 2.52$ \\
& 0900 & 1600 & 7 & $2.24 \pm 0.20$ & $8.43 \pm 0.85$ \\
Corticosterone & 1300 & 1600 & 7 & $1.45 \pm 0.33$ & $9.91 \pm 1.40$ \\
DOC & 1300 & 1600 & 7 & $0.15 \pm 0.03$ & $10.30 \pm 1.20$ \\
& 1300 & 1600 & 6 & $2.74 \pm 0.28$ & $11.99 \pm 1.67$ \\
\hline
\end{tabular}

* Ovarian venous blood was collected for $15 \mathrm{~min}$ from the time indicated in the table.

** Mean \pm S. E.

MAP: Medroxyprogesterone acetate,

DOC: Desoxycorticosterone. 
at $13.00 \mathrm{hr}$. This is the same as the result obtained by progesterone injection (Fig. 1). The secretion of $20 \alpha-\mathrm{OH}-\mathrm{P}$ is increased by treatment with medroxyprogesterone, corticosterone, or DOC. It seems, therefore, that the secretory rate of $20 \alpha-\mathrm{OH}-\mathrm{P}$ does not always fluctuate in parallel with that of progesterone, although simultaneous increases in both progestin secretions are seen under certain conditions; i.e. progesterone injection at $11.00 \mathrm{hr}$ in Figure 1, the highest dose of progesterone in Table 1, and that of DOC in Table 3.

\section{Discussion}

The present and previous (Uchida et al., 1969c) data demonstrate that preovulatory increase in progesterone secretion is induced by exogenous progesterone given not earlier than $03.00 \mathrm{hr}$ on the morning of proestrus, that maximal stimulation is elicited by injection at $11.00 \mathrm{hr}$, and that injection at 01.00 or $15.00 \mathrm{hr}$ fails to increase ovarian progesterone secretion at $16.00 \mathrm{hr}$ in 4-day cyclic rats under our lighting schedule (08.00-20.00 hr). This agrees with the observation of Kobayashi et al. (1969a and 1969b) of our laboratory who demonstrated under the same conditions that progesterone injected at $02.00 \mathrm{hr}$ or earlier on the day of proestrus delayed the coming ovulation, whereas the injection at $05.00 \mathrm{hr}$ or later advanced the $\mathrm{LH}$ release as well as the subsequent ovulation by 2 to $3 \mathrm{hr}$. These facts suggest that the responsiveness to progesterone of the central nervous mechanism regulating the ovulating hormone release becomes activated sometime between 01.00 and $03.00 \mathrm{hr}$ on the day of proestrus.

As shown in the previous papers (Uchida et al., 1969a and 1969b), preovulatory progesterone secretion in our rats starts to increase from about $17.00 \mathrm{hr}$ on the day of proestrus and attains the maximum within $30 \mathrm{~min}$, the average level of this is around $3 \mu \mathrm{g} / \mathrm{hr} /$ ovary, lasting for several hours. Further, LH preparations given intravenously stimulate ovarian progesterone secretion in rats hypophysectomized just before the critical time for $\mathrm{LH}$ release, and the maximal stimulation caused by exogenous $\mathrm{LH}$ is equivalent to the spontaneous increase. A single intravenous injection of 5 to $10 \mu \mathrm{g}$ per rat of NIH-LH-S $\mathrm{S}_{12}$ is enough to cause the maximal response of around $3 \mu \mathrm{g} / \mathrm{hr} /$ ovary (Uchida et al., 1969b). However, the ovarian progesterone secretory rate at $16.00 \mathrm{hr}$ in rats given progesterone at 09.00 or $11.00 \mathrm{hr}$ (Fig. 1) is nearly twice the maximal value of spontaneous or LH induced increases. A similar "supersecretion" of progesterone is observed at $19.00 \mathrm{hr}$ in rats given progesterone at 13.00 or $15.00 \mathrm{hr}$ (Table 2) as well as in rats given norethisterone at 09.00 hr (Table 3).

In order to confirm this "supersecretion" of progesterone, the individual values of progesterone secretory rates in rats receiving the various treatments used in both the present and previous experiments (Uchida et al., $1969 \mathrm{~b}$ and 1969c) were classified into four groups designated as follows: a) no increase for values less than $0.5 \mu \mathrm{g} / \mathrm{hr} /$ ovary, b) moderate for values from 0.5 to $1.5 \mu \mathrm{g} / \mathrm{hr} /$ ovary, c) maximal for values from 1.5 to 4.0 $\mu \mathrm{g} / \mathrm{hr} /$ ovary, and d) "supersecretion" for values over $4.0 \mu \mathrm{g} / \mathrm{hr} /$ ovary. The relation between the treatments and the distribution of progesterone secretory rates is presented in Table 4. The time of $16.00 \mathrm{hr}$ is so close to the onset of spontaneous increase in preovulatory progesterone secretion that the increase occurs in one out of 10 rats at $16.00 \mathrm{hr}$ without any treatment (Case 1). A similar incidental increase is observed in the group given estradiol (Case 23). In the control rats at $19.00 \mathrm{hr}$, "supersecretion" of progesterone occurs in only one out of 9 rats (Case 3), but it is observed in high frequency in the rats treated with progesterone (Cases 7,8,9,12, and 13). From the above data, it is considered that a relatively large dose of more than $1 \mathrm{mg}$ of progesterone (Case 7), and a sufficient interval of over 4 or $5 \mathrm{hr}$ after the injection (Cases 9 and 13) are required for the manifestation of 
"supersecretion" of progesterone in the afternoon of proestrus.

Since exogenous progesterone does not increase ovarian progesterone secretion when rats are hypophysectomized or phenobarbitalized just before progesterone treatment (Uchida et al., 1969c), the site of action of progesterone must be somewhere in the neural process regulating $\mathrm{LH}$ release from the pituitary. However, the direct action of progesterone on the ovary can not be excluded. Nallar et al. (1966) showed that pretreatment with progesterone markedly increased the plasma LH level in proestrous rats, but it is not likely that an enormously high level of plasma LH is responsible for the "supersecretion" of progesterone, since overdoses of $\mathrm{LH}$ preparations never cause a "supersecretion" of progesterone, the secretion rate of which is beyond the maximal value of $3 \mu \mathrm{g} / \mathrm{hr} /$ ovary in our cyclic rats (Uchida et al., 1969b). It is assumed, therefore, either that progesterone has a direct action on the ovary, or that progesterone facilitates the release of a pituitary factor(s) which is other than LH but acts synergistically with $\mathrm{LH}$ to favor progesterone secretion from the ovary.

With regard to the direct action of progesterone on the ovary, Figure 1 reflects the change of ovarian sensitivity to progesterone. The period from 09.00 through $11.00 \mathrm{hr}$ on the day of proestrus is optimal for progesterone treatment which makes the ovary so sensitive to LH that the advanced "supersecretion" of progesterone takes place. Taking account of the result obtained by Hori et al. (1968) of our laboratory, the above period of time coincides well with the time when ovarian estrogen secretion increases rapidly to attain the maximum. Kobayashi et al. (1969b) of our laboratory suggested that the integrated amount of estrogen secreted during the afternoon of diestrus through the morning of proestrus was responsible for the neural mechanism(s) which induced ovulatory discharge of $\mathrm{LH}$ and the partial amount of estrogen secreted during the time between 04.00 and
$07.00 \mathrm{hr}$ probably acted as a trigger for $\mathrm{LH}$ release. It is considered, therefore, that the progesterone advancement of LH release may be an accerelating effect of exogenous progesterone on the triggering action of endogenous estrogen on LH release, and the "supersecretion" of progesterone induced by exogenous progesterone may be due to increased ovarian responsiveness to $\mathrm{LH}$, a state produced by progesterone given when ovarian estrogen secretion is nearly maximal. These results obtained by exogenous progesterone do not necessarily mean the physiological significance of endogenous progesterone, since enough progesterone to cause advancement of LH release as well as ovarian "supersecretion" of progesterone is not secreted from the ovary before LH discharge in our rats (Uchida et al., 1969a). Both phenomena, advancement of $\mathrm{LH}$ release and ovarian "supersecretion" of progesterone, may be useful for the biological characterization of progestational compounds.

Compounds having progestational activity, for example, norethisterone, MAP, and DOC, also facilitate $\mathrm{LH}$ release, this is substantiated by an increase in ovarian progesterone secretion before the time of the spontaneous $\mathrm{LH}$ discharge in rats. This activity of the steroid, however, does not appear to parallel its progestational potency. MAP was reported to be about 40 times as active as progesterone in the bioassay based on endometrial carbonic anhydrase activity in rabbits (Miyake et al., 1965), whereas the facilitation of $\mathrm{LH}$ release by MAP is apparently weaker than that by progesterone (Table 4). The above steroids cause the advancement of $\mathrm{LH}$ release without causing "supersecretion" of progesterone. Medroxyprogesterone and corticosterone appear to be inactive for accerelating $\mathrm{LH}$ release. The lack of parallelism in these activities can not be explained at present, but it suffices here to point out that a naturally occurring progestin, progesterone, is more active in facilitation of $\mathrm{LH}$ release than a potent synthetic progestin, MAP.

Summarizing the data on the effects of 
Table 4. Distribution of individual values of ovarian progesterone secretory rates in proestrous rats given various treatments and in the controls

\begin{tabular}{|c|c|c|c|c|c|c|c|c|c|}
\hline \multirow{2}{*}{$\begin{array}{l}\text { Case } \\
\text { No. }\end{array}$} & \multirow{2}{*}{ Treatment } & \multirow{2}{*}{$\begin{array}{l}\text { Dose } \\
(\mathrm{mg})\end{array}$} & \multirow{2}{*}{$\begin{array}{c}\text { Time } \\
\text { of } \\
\text { injection }\end{array}$} & \multirow{2}{*}{$\begin{array}{l}\text { Time of } \\
\text { blood } \\
\text { collection }\end{array}$} & \multicolumn{4}{|c|}{$\begin{array}{l}\text { Ovarian progesterone secretory rate } \\
(\mu \mathrm{g} / \mathrm{hr} / \text { ovary })\end{array}$} & \multirow{2}{*}{$\begin{array}{c}\text { Total } \\
\text { numbers } \\
\text { of } \\
\text { rats }\end{array}$} \\
\hline & & & & & $\begin{array}{l}\text { no change } \\
(<0.5)\end{array}$ & $\begin{array}{l}\text { moderate } \\
(0.5-1.5)\end{array}$ & $\begin{array}{l}\operatorname{maximal} \\
(1.5-4.0) \\
\end{array}$ & $\begin{array}{l}\text { super } \\
(>4.0)\end{array}$ & \\
\hline 1 & Control & & & 1600 & 9 & 0 & 1 & 0 & 10 \\
\hline 2 & Control & & & 1700 & 1 & 5 & 3 & 0 & 9 \\
\hline 3 & Control & & & 1900 & 0 & 0 & 8 & 1 & 9 \\
\hline 4 & Progesterone & 0.05 & 1100 & 1600 & 7 & 0 & 0 & 0 & 7 \\
\hline 5 & Progesterone & 0.2 & 1100 & 1600 & 0 & 4 & 2 & 0 & 6 \\
\hline 6 & Progesterone & 0.5 & 1100 & 1600 & 0 & 4 & 3 & 0 & 7 \\
\hline 7 & Progesterone & 1 & 1100 & 1600 & 0 & 0 & 3 & 4 & 7 \\
\hline 8 & Progesterone & 5 & 1100 & 1600 & 0 & 0 & 2 & 4 & 6 \\
\hline 9 & Progesterone & 5 & 0900 & 1600 & 0 & 0 & 3 & 4 & 7 \\
\hline 10 & Progesterone & 5 & 1300 & 1600 & 0 & 0 & 6 & 1 & 7 \\
\hline 11 & Progesterone & 5 & 1500 & 1600 & 6 & 2 & 1 & 0 & 9 \\
\hline 12 & Progesterone & 5 & 1300 & 1900 & 0 & 0 & 6 & 5 & 11 \\
\hline 13 & Progesterone & 5 & 1500 & 1900 & 0 & 0 & 4 & 8 & 12 \\
\hline 14 & MAP & 5 & 0900 & 1600 & 0 & 0 & 7 & 0 & 7 \\
\hline 15 & MAP & 5 & 1300 & 1600 & 0 & 5 & 2 & 0 & 7 \\
\hline 16 & Medroxyprogesterone & 5 & 0900 & 1600 & 9 & 0 & 0 & 0 & 9 \\
\hline 17 & Medroxyprogesterone & 5 & 1300 & 1600 & 1 & 4 & 0 & 0 & 5 \\
\hline 18 & Corticosterone & 5 & 1300 & 1600 & 7 & 0 & 0 & 0 & 7 \\
\hline 19 & DOC & 5 & 1300 & 1600 & 0 & 0 & 6 & 0 & 6 \\
\hline 20 & Norethisterone & 5 & 0900 & 1600 & 0 & 0 & 5 & 1 & 6 \\
\hline 21 & Norethisterone & 5 & 1300 & 1600 & 3 & 5 & 3 & 0 & 11 \\
\hline 22 & Norethisterone & 5 & 1300 & 1900 & 0 & 0 & 5 & 2 & 7 \\
\hline 23 & Estradiol & 5 & 1300 & 1600 & 3 & 3 & 1 & 0 & 7 \\
\hline 24 & $20 \alpha-\mathrm{OH}-\mathbf{P}$ & 5 & 1300 & 1600 & 6 & 0 & 0 & 0 & 6 \\
\hline
\end{tabular}

Table 5. Comparison of the responses in ovarian progesterone and 20 $\alpha$-hydroxypregn-4-en-4-one (20 $\alpha-$ $\mathrm{OH}-\mathrm{P})$ secretions

\begin{tabular}{|c|c|c|c|}
\hline \multirow{2}{*}{\multicolumn{2}{|c|}{ Source of data }} & \multicolumn{2}{|c|}{ Ovarian secretion } \\
\hline & & \multirow{2}{*}{$\begin{array}{c}\text { Progesterone } \\
\text { no change }\end{array}$} & \multirow{2}{*}{$\frac{20 \alpha-\mathrm{OH}-\mathrm{P}}{\text { decrease }}$} \\
\hline Figure & Progesterone at 0100 & & \\
\hline Figure & Progesterone at 0700 & increase & no change \\
\hline Figure & Progesterone at 1100 & increase & increase \\
\hline Table & Progesterone $0.05 \mathrm{mg}$ & no change & decrease \\
\hline Table & Progesterone $1 \mathrm{mg}$ & increase & no change \\
\hline Table & Progesterone $5 \mathrm{mg}$ & increase & increase \\
\hline Table & Norethisterone & increase & no change \\
\hline Table & Medroxyprogesterone & no change & increase \\
\hline Table & MAP & increase & no change \\
\hline Table & Corticosterone & no change & increase \\
\hline Table & DOC & increase & increase \\
\hline
\end{tabular}


exogenous progestins on the ovarian secretions of progesterone and $20 \alpha-\mathrm{OH}-\mathrm{P}$ (Table

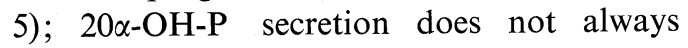
change in parallel with progesterone: the secretion rate of $20 \alpha-\mathrm{OH}-\mathrm{P}$ at $16.00 \mathrm{hr}$ during proestrus appears to be depressed either by the treatment with small doses of progesterone (Table 1) or by the treatment before $05.00 \mathrm{hr}$ on the same day (Fig. 1), medroxyprogesterone, corticosterone, and DOC (Table 3), increase the secretory rate of this steroid. From these results, it is speculated that a) progesterone and other progestational compounds may directly or indirectly inhibit the production of $20 \alpha-\mathrm{OH}-\mathrm{P}$ in the ovary under certain conditions, b) a significant portion of the $20 \alpha-\mathrm{OH}-\mathrm{P}$ secreted at a basal level is produced at a different ovarian site from progesterone, and c) the secretion of $20 \alpha-\mathrm{OH}-$ $\mathrm{P}$ increasing in parallel with that of progesterone may be due to the action of $20 \alpha-$ hydroxysteroid dehydrogenase, the physiological significance of which was discussed by Wiest et al. (1968).

\section{Acknowledgement}

The valuable technical assistance of Messrs. Yasuharu Nomura and Kenji Miyata is gratefully acknowledged.

\section{References}

Byrnes, W. W. and E. G. Shipley (1955). Endocrinology 57, 5.

Engle, C. R. and R. L. Noble (1956). J. Endocrinol. 14, 16.

Engle, C. R. and R. L. Noble (1957). Endocrin$\operatorname{olog} y \mathbf{6 1}, 318$.

Hori, T., M. Ide and T. Miyake (1968). Endocrinol. Japon. 15, 215.

Kobayashi, F., K. Hara and T. Miyake (1968). Ibid. 15, 313.

Kobayashi, F., K. Hara and T. Miyake (1969a). Ibid. 16, 251.

Kobayashi, F., K. Hara and T. Miyake (1969b). Ibid. (in press).

Marvin, H. N. (1947). Anat. Record 98, 383. Marvin, H. N. (1958). Proc. Soc. Exptl. Biol. Med. 97, 197.

McCormack, C. E. and R. K. Meyer (1965). Fertil. Steril. 16, 384.

Miyake, T., F. Kobayashi, K. Horibe, E. Itoga, H. Kakushi, Y. Nomura, M. Kadowaki, K. Odaguchi, K. Hara, T. Fukukawa and T. Ide (1965). Folia Endocrinol. Japon. 41, 1079.

Nallar, R., J. Antunes-Robrigues and S. M. McCann (1966). Endocrinology 79, 907.

Uchida, K., M. Kadowaki and T. Miyake (1969a). Endocrinol. Japon. 16, 227.

Uchida, K., M. Kadowaki and T. Miyake (1969b). Ibid 16, 239.

Uchida, K., M. Kadowaki and T. Miyake (1969c). Ibid. (in press).

Wiest, W. G., W. R. Kidwell and K. Balogh, Jr. (1968). Endocrinology 82, 844. 